\title{
BRAF NM_004333.4:C.1798G>A
}

National Cancer Institute

\section{Source}

National Cancer Institute. BRAFNM 004333.4:C.1798G>A. NCI Thesaurus. Code C98352.

A nucleotide substitution at position 1798 of the coding sequence of the BRAF gene where guanine has been mutated to adenine. 